\begin{tabular}{|l|c|c|c|r|}
\hline $\begin{array}{l}\text { Cuadernos de Investigación Geográfica } \\
\text { Geographical Research Letters }\end{array}$ & 2017 & N $^{\circ} 43(1)$ & pp. 63-81 & $\begin{array}{r}\text { ISSN 0211-6820 } \\
\text { eISSN 1697-9540 }\end{array}$ \\
\hline
\end{tabular}

\title{
SET-UP AND CALIBRATION OF A PORTABLE SMALL SCALE RAINFALL SIMULATOR FOR ASSESSING SOIL EROSION PROCESSES AT INTERRILL SCALE
}

\section{J.J. ZEMKE}

\begin{abstract}
Department of Geography, Institute for Integrated Natural Sciences, University Koblenz-Landau,
\end{abstract} Universitätsstrasse 1, D-56070 Koblenz, Germany.

\begin{abstract}
A portable rainfall simulator was built for assessing runoff and soil erosion processes at interrill scale. Within this study, requirements and constraints of the rainfall simulator are identified and discussed. The focus lies on the calibration of the simulator with regard to spatial rainfall homogeneity, rainfall intensity, drop size, drop fall velocity and rainfall kinetic energy. These parameters were obtained using different methods including a Laser Precipitation Monitor. A detailed presentation of the operational characteristics is given. The presented rainfall simulator setup featured a rainfall intensity of $45.4 \mathrm{~mm} \cdot h^{-1}$ with a spatial homogeneity of $80.4 \%$ based on a plot area of $0.64 \mathrm{~m}^{2}$. Because of the comparatively low drop height $(2 \mathrm{~m})$, the diameter-dependent terminal fall velocity $\left(1.87 \mathrm{~m} \cdot \mathrm{s}^{-1}\right)$ was lower than benchmark values for natural rainfall. This conditioned also a reduced rainfall kinetic energy $\left(4.6 \mathrm{~J} \cdot \mathrm{m}^{-2} \cdot \mathrm{mm}^{-1}\right)$ compared to natural rainfall with same intensity. These shortfalls, a common phenomenon concerning portable rainfall simulators, represented the best possible trade-off between all relevant rainfall parameters obtained with the given simulator setup. Field experiments proved that the rainfall erosivity was constant and replicable.
\end{abstract}

\section{Configuración y calibración de un simulador de lluvia portátil para determinar procesos de erosión del suelo a escala de interrill}

RESUMEN. Se construyó un simulador de lluvia portátil con el fin de determinar procesos de escorrentía y erosión del suelo a escala de interrill. En este estudio se identifican y discuten los requisitos y las limitaciones de este simulador de lluvia. Para ello se examinan algunos aspectos relacionados con la calibración del simulador tales como la homogeneidad espacial de la lluvia, la intensidad de la lluvia, el tamaño y velocidad de las gotas y la energía cinética de la lluvia. Estos parámetros fueron obtenidos utilizando diferentes metodologías, entre las que cabe destacar un Monitor Láser de Precipitación (Laser Precipitation Monitor). En este trabajo se presentan de forma detallada las características de la calibración. La intensidad de la lluvia obtenida por el simulador fue de 45.4 $m m h^{-1}$, con una homogeneidad espacial del $84 \%$ sobre una parcela con una 
superficie de $0.64 \mathrm{~m}^{2}$. Debido a que la altura de la caída de las gotas de lluvia fue relativamente baja $(2 \mathrm{~m})$, la velocidad final de las gotas $\left(1.87 \mathrm{~m} \mathrm{~s}^{-1}\right)$, que depende del diámetro de las mismas, fue menor que los valores establecidos para lluvias naturales. Esto también determinó una energía cinética baja (4.6 J·m $\left.{ }^{2} \cdot \mathrm{mm}^{-1}\right)$, comparada con la de las lluvias naturales de misma intensidad. Estas limitaciones, habituales en los simuladores de lluvia portátiles, constituyeron un mal menor teniendo en cuenta todos los parámetros de lluvia relevantes obtenidos con este simulador. Por otra parte, los experimentos de campo mostraron que la erosividad de la lluvia fue constante y replicable.

Key words: runoff, soil erosion, rainfall erosivity, rainfall kinetic energy, rainfall simulation.

Palabras clave: escorrentía, erosión del suelo, erosividad de la lluvia, energía cinética, simulación de lluvia.

* Corresponding author: Julian Johannes Zemke, Department of Geography, Institute for Integrated Natural Sciences, University Koblenz-Landau, Universitätsstrasse 1, D-56070 Koblenz, Germany. E-mail address: zemke@uni-koblenz.de

\section{Introduction}

Rainfall simulators are a widely used tool in geomorphology and soil science when it comes to investigating soil hydrological properties and soil erosion processes (e.g. Ries et al., 2009; Foltz et al., 2009; Arnáez et al., 2004; Cerdà et al., 1997). They allow simulating rainfall events with almost any desired intensity and duration. This is of special value when examining heavy rainfall events that trigger the majority of soil erosion in most catchments (Maetens et al., 2012; Morgan, 2009; Fransen et al., 2001; MacDonald et al., 2001; Arnáez and Larrea, 1995; Edwards and Owens, 1991). Soil erosion is caused by the high kinetic energy of impacting raindrops that cause particle detachment and transport. Secondly, soil erosion might occur through overland flow that occurs when rainfall intensities exceed the infiltration rates of the topsoil, eventually leading to Hortonian overland flow (Butzen et al., 2014).

These high intensity events normally have a rather long return period, making it difficult to observe a high number of events within a defined time interval and a defined area. Furthermore, high-intensity rainfalls are often confined to small areas as they are usually related to convective precipitation events of single storm cells. At last, the physical rainfall properties are inconstant during an event, making it extremely difficult to obtain the parameters regulating soil erosion processes, which are most importantly the drop size distribution and the terminal fall velocity, both conditioning rainfall kinetic energy (De Vente et al., 2013; Petan et al., 2010; Assouline 2009; Dunkerley, 2008; Arnáez et al., 2007; Morin et al., 2006; Usón and Ramos, 2001; Salles and Poesen, 2000; Chaubey et al., 1999). 
Because of that, it is evident that a predictable simulation of heavy rainfall events offers many advantages for the in-situ observation of soil erosion processes. Yet, a rainfall simulator has to fulfil several requirements to ensure sound results, like realistic drop fall velocities, rainfall intensities, spatial rainfall homogeneity and a reliable replication of desired rainfall parameters (Blanquies et al., 2003). That is why an extensive calibration is obligatory when setting up a simulator. A concept and results for such a calibration are provided within this study, with the aim of emphasizing and discussing possible uncertainties that arise when conducting a high-precision calibration. Results of field experiments are incorporated in a subsequent discussion of the simulator working specifications.

\section{Materials and Methods}

\subsection{Portable rainfall simulator}

The portable rainfall simulator was designed to meet the most important demands, a good mobility for operation in rough terrain with at the same time reliable and constant rainfall characteristics. It was designed and built based on the structural design of Iserloh et al. (2012), consisting of four different components: rack, water circuit, electric circuit and plot frame.

The rack was built as a 1x1 m aluminium frame with four telescoping aluminium legs attached to each corner of the head piece. The nozzle height was set to 2 meters above the plot surface. During the simulations, drop height was checked by laser distance measuring. The telescoping legs allowed to align the head piece horizontally even in steep terrain. A transparent tarpaulin was attached to the rack, functioning as a windshield to ensure no disturbance of the artificial rainfall.

The water circuit was made up of an electric bilge pump with a maximum delivery height of $4.5 \mathrm{~m}$ which was connected to a hose that led to a full cone nozzle (Type Lechler 460.608), positioned at the centre of the simulator head part. Both components were used in numerous studies (e.g. Rodrigo Comino et al., 2016; Butzen et al., 2014; Iserloh et al., 2012) and showed a good reliability during field work and also stable rainfall characteristics. The water flow was controlled by a gate valve located directly at the pump outlet. An analogical manometer mounted at nozzle height was used to monitor the operating pressure which was considered to be the major control factor for rainfall intensity and drop spectrum.

The electric circuit consisted of a $12 \mathrm{~V}$ lead-fleece battery with a capacity of $12 \mathrm{Ah}$, potentially enabling a continuous operation lasting four hours. The circuit was controlled by a two-way switch and protected from possible short-circuits by a fuse. All of the components fitted in a common metal case, allowing an easy transportation.

The plot frame limiting the observation area was dimensioned on basis of the calibration results (cf. chapters 2.2 and 3.1) and built out of a seamless piece of stainless steel with a width of $10 \mathrm{~cm}$ and a thickness of $2 \mathrm{~mm}$. A size of $0.8 \cdot 0.8 \mathrm{~m}$ showed a good compromise between a preferably large area and spatially homogeneous rainfall 
characteristics. As it was planned to use the frame on compacted soils, the penetration depth was limited to $4 \mathrm{~cm}$. On one side of the frame, an apron was built by folding the upper $6 \mathrm{~cm}$ of the frame in an angle of $90^{\circ}$. Here, a circumferential edge was welded on, leaving only a small gap of $2 \mathrm{~cm}$ through which the runoff and eroded sediment could leave the plot. Additionally, two baffles were attached to ensure a direct transport of the material towards the outlet. Figure 1 shows both the rainfall simulator setup and the plot frame. The rainfall characteristics, obtained during an extensive calibration (cf. chapter 2.2 and 3), are shown in Table 1.

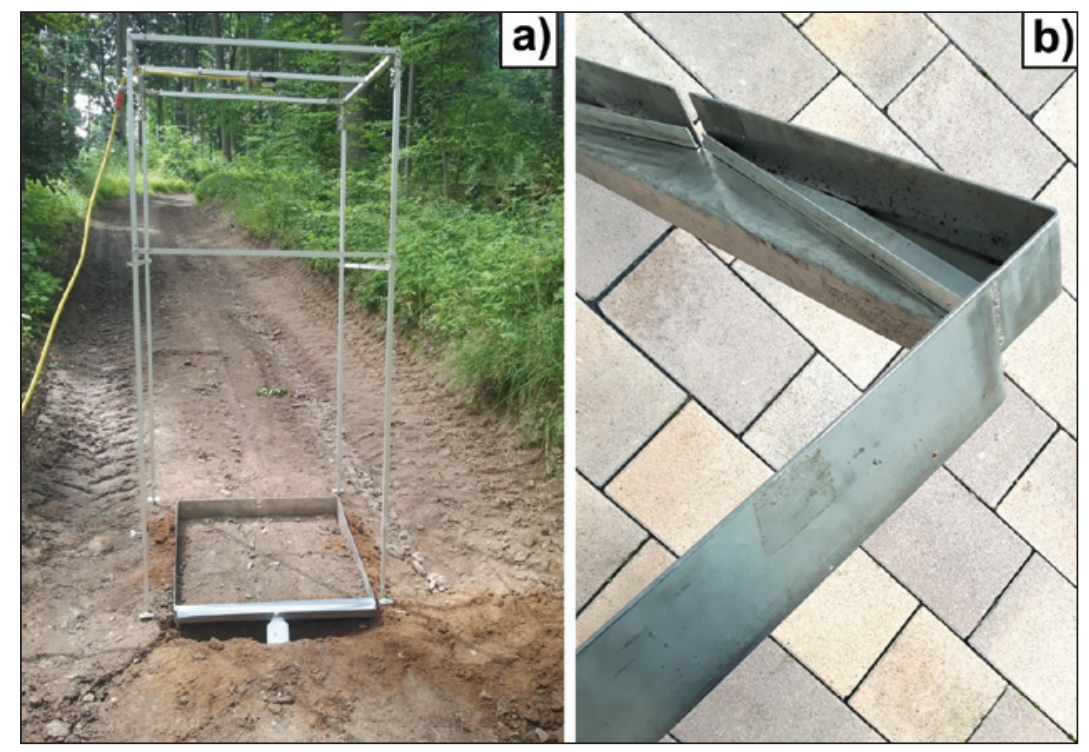

Figure 1. a) Rainfall simulator (tarpaulin removed for a better visibility); b) Close-up of the plot frame outlet.

Table 1. Operational characteristics of the Koblenz rainfall simulator.

\begin{tabular}{cc}
\hline Parameter & Value \\
\hline Nozzle & Lechler 460.608 \\
Drop height & $2 \mathrm{~m}$ \\
Operating pressure & $0.09 \mathrm{bar}$ \\
Intensity & $45.4 \mathrm{~mm} \cdot \mathrm{h}^{-1}$ \\
Plot surface & $0.64 \mathrm{~m}^{2}$ \\
Water applied to plot surface & $0.481 \cdot \mathrm{min}^{-1}$ \\
Water consumption & $11 \cdot \mathrm{min}^{-1}$ \\
Working efficiency & $48 \%$ \\
Uniformity coefficient & $80.4 \%$ \\
Median drop diameter & $0.28 \mathrm{~mm}$ \\
Mean fall velocity & $1.87 \mathrm{~m} \cdot \mathrm{s}^{-1}$ \\
Mean rainfall kinetic energy & $4.6 \mathrm{~J} \cdot \mathrm{m}^{-2} \cdot \mathrm{mm}^{-1}$ \\
\hline
\end{tabular}




\subsection{Calibration setup}

To ensure replicable and constant rainfall characteristics, a calibration of the simulator was conducted. An additional aim of the calibration was to obtain rainfall characteristics similar to those of natural events.

The calibration comprised three different methods. In a first step, the spatial rainfall distribution on the plot surface and the rainfall intensity were measured. To obtain datasets with a high spatial resolution, 263 circular rainfall collectors with a diameter of $6 \mathrm{~cm}$ and placed on an area of 1x1 m under the nozzle were used. After 15 minutes of artificial rainfall, each collector was weighed to determine the quantity of rainfall collected. As the relative position of the collectors was known, a point-dataset of rainfall intensities could be derived from the measurements. With the help of this dataset, a rainfall intensity map was obtained using a Kriging interpolation. On the basis of the point-dataset, the spatial homogeneity of the rainfall was calculated using the uniformity coefficient (UC) of Christiansen (1942):

$$
U C=1-\left(\frac{\sum\left|P_{i}-P_{m}\right|}{\sum P_{i}}\right)
$$

Where: $\mathrm{UC}=$ Uniformity coefficient $[\%] ; \mathrm{P}_{\mathrm{i}}=$ Water collected in collector $\mathrm{i}[\mathrm{mm}]$; $\mathrm{P}_{\mathrm{m}}=$ Mean value of water collected in all collectors $[\mathrm{mm}]$.

In a second step, one large, plot-sized collector was used to determine net rainfall intensities. As the gravimetric analysis of 263 collectors was rather time-consuming, a single wooden collector with the dimensions of the plot surface $(0.8 \times 0.8 \mathrm{~m})$ was built to gain a mean total intensity for the whole plot surface more quickly. The second advantage of this method was the absence of small gaps between the circular collectors which led to lower rainfall intensities when summing up each individual quantity in the small collectors.

When looking only at the hydrology, a homogenous and constant rainfall intensity is sufficient to give authoritative forecasts, as the output (runoff) of a plot area can be measured, while the input (rainfall) is known. In contrast, when looking at soil particle detachment, the kinetic energy of the rainfall, controlling the rainfall erosivity is of interest. As kinetic energy depends on the velocity and the mass - alternatively the diameter - of the raindrops, both have to be measured in order to calculate rainfall erosivity.

That is why, in a third step, drop size distribution and terminal fall velocity were measured using a Laser Precipitation Monitor (LPM) device (Thies Clima). With the help of the LPM, it was possible to measure both the drop diameter and fall velocity of all drops falling through an emitted laser beam contact-free in real time. The LPM was placed at 9 different positions under the rainfall simulator; the minimum measurement time at each position was 15 minutes. Again, the results were plotted as a Kriginginterpolated map covering the plot surface. Following Iserloh et al. (2012) and Fornis et al. (2005), the kinetic energy of the artificial rainfall was calculated on the basis of the LPM results: 


$$
K E=\frac{\left(\frac{\pi}{12}\right) \cdot\left(\frac{1}{10^{6}}\right) \cdot\left(\frac{3600}{t}\right) \cdot\left(\frac{1}{A_{L P M}}\right) \cdot \sum n_{i} \cdot d_{i}^{3} \cdot\left(v_{d_{i}}\right)^{2}}{I}
$$

Where: $\mathrm{KE}=$ Rainfall kinetic energy $\left[\mathrm{J} \cdot \mathrm{m}^{-2} \cdot \mathrm{mm}^{-1}\right] ; \mathrm{t}=$ Time interval $(=60 \mathrm{sec}) ; \mathrm{A}_{\mathrm{LPM}}$ $=$ Measurement plane of the LPM $\left(=0.00456 \mathrm{~m}^{2}\right) ; \mathrm{n}_{\mathrm{i}}=$ Drop count in the drop spectrum raster cell $\mathrm{i} ; \mathrm{d}_{\mathrm{i}}=$ Mean drop diameter of drop spectrum class $\mathrm{i}[\mathrm{cm}] ; \mathrm{v}_{\mathrm{di}}=$ Mean drop velocity of drops with a mean diameter of $d_{i}\left[\mathrm{~cm}^{-1} \mathrm{~s}^{-1}\right] ; \mathrm{I}=$ Rainfall intensity $\left[\mathrm{mm} \cdot \mathrm{h}^{-1}\right] ; \mathrm{d}=$ Drop diameter $[\mathrm{mm}]$.

To evaluate the quality of the artificial rainfall against the natural rainfall characteristics, several benchmarks were derived from empirical studies discussing properties of natural rainfall. Marshall and Palmer (1948) formulated the Marshall-Palmer-Distribution (MPD), a relationship between relative drop size distribution and rainfall intensity:

$$
N_{d}=0.08 \cdot e^{-\left(41 * I^{-0.21}\right) \cdot d}
$$

Where: $\mathrm{N}_{\mathrm{d}}=$ Volume of all drops up to a diameter of $\mathrm{d}$ per $\mathrm{mm}$ of rainfall $\left[\mathrm{m}^{3} \cdot \mathrm{mm}^{-1}\right]$; $\mathrm{I}=$ Rainfall intensity $\left[\mathrm{mm} \cdot \mathrm{h}^{-1}\right] ; \mathrm{d}=$ Drop diameter $[\mathrm{mm}]$.

The MPD states that the percentage of larger raindrops rises with increasing rainfall intensity. In another study, Gunn and Kinzer (1949) showed that there is a correlation between drop size and fall velocity, with larger drops showing higher fall velocities than smaller drops. Nevertheless, this correlation is not linear, as the fall velocities flatten out due to the increasing friction losses that go along with increased drop diameter. Concerning the observed diameter range $(0.01-0.58 \mathrm{~cm})$, the following regression curve can be assumed:

$$
v=56.6 \cdot d^{3}-90.4 \cdot d^{2}+49.6 \cdot d-0.2
$$

Where: $\mathrm{v}=$ Raindrop fall velocity $\left[\mathrm{cm} \cdot \mathrm{s}^{-1}\right] ; \mathrm{d}=$ Raindrop diameter $[\mathrm{cm}]$.

Additionally, van Dijk et al. (2002) determined the correlation between rainfall intensity and rainfall kinetic energy, stating an exponential dependency between both parameters:

$$
K E=28.3 \cdot\left(1-0.52 \cdot e^{-0.042 \cdot I}\right)
$$

Where: $\mathrm{KE}=$ Kinetic energy per square meter and $\mathrm{mm}$ rainfall $\left[\mathrm{J} \cdot \mathrm{m}^{-2} \cdot \mathrm{mm}^{-1}\right] ; \mathrm{I}=$ Rainfall intensity $\left[\mathrm{mm} \cdot \mathrm{h}^{-1}\right]$.

From all this it is evident that higher natural rainfall intensities lead to larger drops conditioning higher fall velocities. This is why the kinetic energy of the rainfall increases with higher rainfall intensities.LPM data allowed not only verifying this causal chain for the artificial rainfall, but also evaluating the drop spectrum (size- and velocity-distribution) precisely.

The most important parameters for the desired simulator output were a good spatial homogeneity of rainfall intensity and sufficient rainfall erosivity for soil erosion processes. Simultaneously, the rainfall intensity should not exceed the values usually 
observed in heavy rainfalls in the study area, located in German low mountain ranges. Therefore, a target intensity of $40-50 \mathrm{~mm} \cdot \mathrm{h}^{-1}$ was defined.

At the beginning of the calibration, constraints caused by the structural design of the rainfall simulator had to be considered. Thus, we assumed that the fall velocity of the artificial raindrops would be lower compared to natural raindrops of the same size. The reason for this assumption was the rather low drop height of 2 meters, limiting the acceleration of the generated drops. A higher mounted nozzle would have reduced this problem, but as the structural stability and the flexibility in rough terrain would have been considerably affected with a larger rack, a trade-off between mobility and drop spectrum was sought.

Lower fall velocities lead to lower rainfall kinetic energy, therefore limiting the rainfall erosivity during the simulation runs. This is a basic structural problem concerning the majority of small portable rainfall simulators (Iserloh et al. 2013). To obtain a rainfall erosivity capable of detaching and transporting soil particles, the mean drop mass - hence the diameter - had to be increased by reducing the operating pressure as suggested in e.g., Cerdà et al. (1997). This means that the pressure had to be lowered under the specified minimum working pressure $(0.5$ bar $)$ of the 460 -type nozzle, thus no longer ensuring a homogeneous spray cone. Therefore, a viable pressure had to be determined reaching a compromise between intensity, erosivity and spatial homogeneity.

\subsection{The methodical concept of the field experiments}

The main aim of the field experiments conducted with the simulator was to quantify the influence of forest soil compaction caused by heavy machinery and road construction on runoff generation and soil erosion processes. While they were presented extensively in Zemke (2016), a brief description of a typical experimental setup helps to interpret the findings presented within the discussion of this study.

Generally, three consecutive simulated rainfall events with a duration of 30 minutes were carried out, divided by a short brake of 5 minutes between each event. Superficially flowing water and eroded sediment were collected using wide neck bottles attached to the apron of the plot frame. Bottles were swapped every minute; therefore, a high temporal resolution of the collected data was at hand, which allowed plotting precise runoff and erosion graphs (cf. Zemke 2016).

After each experiment, samples inside and outside of the plot surface were collected using sample rings. Especially with the help of the samples taken outside, in direct vicinity of the plots, it was, amongst other parameters, possible, to measure soil textures of the plot surfaces before soil erosion processes caused by artificial rainfall occurred. The soil textures of these mixed samples were compared with the soil textures of eroded material. Hence, it was possible to verify, if the rainfall erosivity limited particle detachment and transport to specific grain sizes. Apart from that, uniform soil textures of the eroded material, disregarding variable primary soil textures of different plot surfaces, can function as an evidence for constant rainfall erosivity and therefore constant rainfall characteristics during the field experiments. 


\section{Results}

A first calibration run with a fully opened gate valve and a resulting operating pressure of 0.21 bar showed satisfactory results concerning spatial homogeneity as the UC was $85 \%$. Unfortunately, the mean rainfall intensity was $18.4 \mathrm{~mm} \cdot \mathrm{h}^{-1}$, caused by a rather fine spray effect produced by the nozzle. Because of that, the mean rainfall kinetic energy determined with the LPM, was rather low $\left(0.91 \mathrm{~J} \cdot \mathrm{m}^{-2} \cdot \mathrm{mm}^{-1}\right)$. This value represents only $4.3 \%$ of the kinetic energy of a natural rainfall with a similar intensity $\left(21.4 \mathrm{~J} \cdot \mathrm{m}^{-2} \cdot \mathrm{mm}^{-1}\right)$ (van Dijk et al., 2002). Thus, the mean rainfall intensity was lower than primarily planned.

This is why a second calibration with a gate valve half-closed was conducted, to achieve a lower operating pressure of 0.09 bar. Repeated measurements with the plotsized collector showed a mean intensity of $45.4 \mathrm{~mm} \cdot \mathrm{h}^{-1}$, thus being within the target range. Water consumption with 0.09 bar operating pressure was $11 \cdot \mathrm{min}^{-1}$. Therefore, a working efficiency of $48 \%$ was achieved, since $0.481 \cdot \mathrm{m}^{-2}$ were applied to the plot surface area.

The dataset obtained with the help of 263 circular collectors revealed a uniformity coefficient of $80.4 \%$, representing an acceptable value. Nevertheless, an expected UCdecrease due to the lower operating pressure had to be stated. A kriging-interpolation of the collector data showed a circular pattern, representing the spray cone (Fig. 2). The contour map shows the whole area under the rainfall simulator, with the nozzle placed at position (010), and plot size of $0.64 \mathrm{~m}^{2}$.

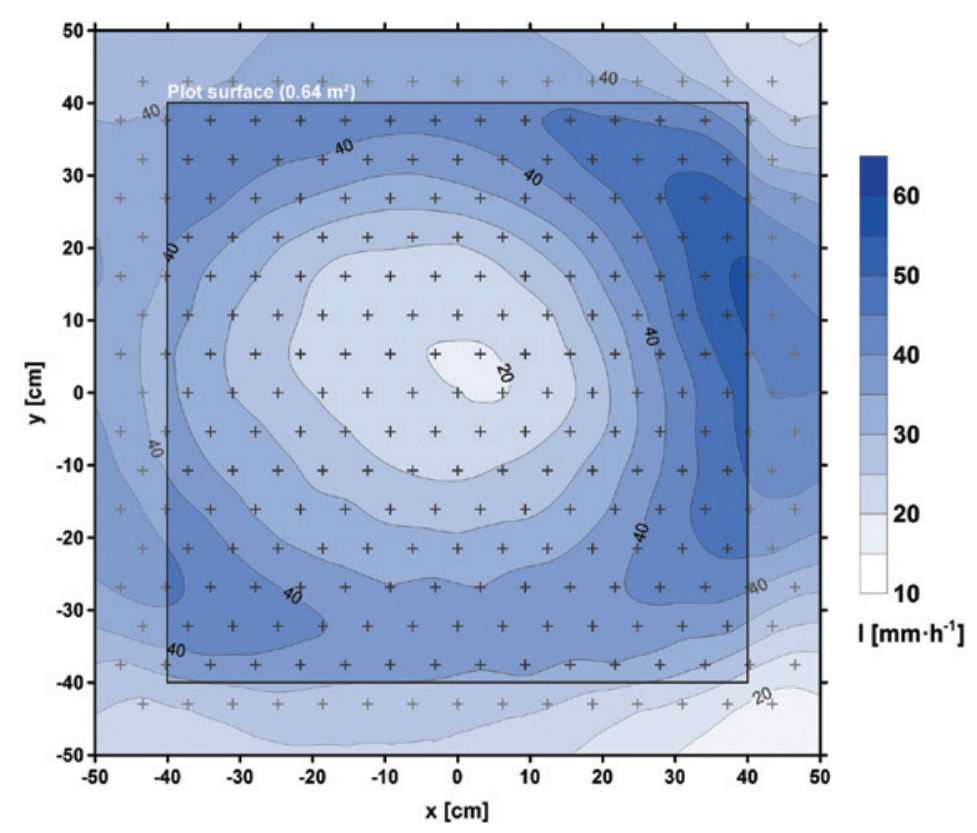

Figure 2. Spatial distribution of rainfall intensity obtained with 263 rainfall collectors (marked as crosses). 
LPM-measurements were conducted by positioning the laser device at nine different positions under the nozzle, covering the projected plot surface area. Overall, a dataset with the duration of 159 minutes was recorded. As the LPM only records velocity- and diameter-classes with a fixed time period of one minute, a classified mean drop spectrum per minute was calculated to provide a summary of the rainfall physical properties on the whole plot surface (Fig. 3). This scheme is in accordance to the LPM results presented in Iserloh et al. (2013), where a standardized drop spectrum visualization for small scale rainfall simulators was suggested in order to provide a better comparability between different setups. The detailed rainfall properties for each position are shown in Table 2.

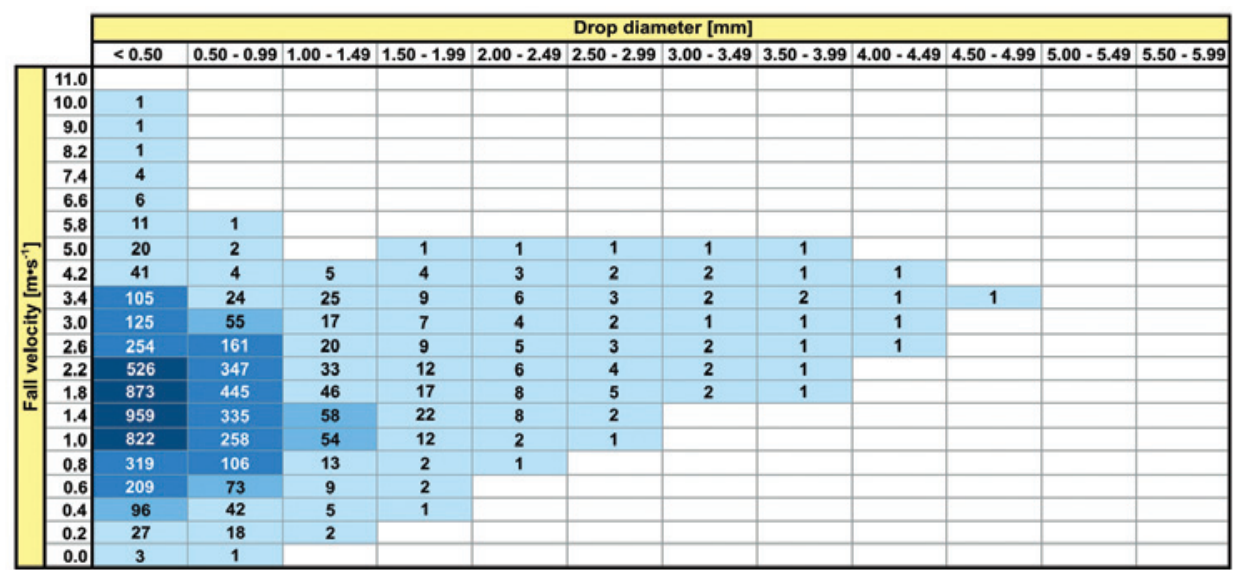

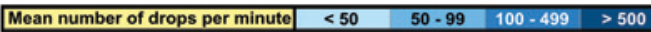

Figure 3. LPM-derived, mean drop spectrum per minute, based on 159 minutes recorded at nine different positions.

Table 2. Position-based LPM results.

\begin{tabular}{ccccc}
\hline $\begin{array}{c}\text { Position } \\
{[\mathbf{c m}]}\end{array}$ & $\begin{array}{c}\text { Drop } \\
\text { count·min }\end{array}$ & $\begin{array}{c}\text { Median drop } \\
\text { diameter }[\mathbf{m m}]\end{array}$ & $\begin{array}{c}\text { Mean fall } \\
\text { velocity }\left[\mathbf{m} \cdot \mathbf{s}^{-1}\right]\end{array}$ & $\begin{array}{c}\text { Mean KE } \\
{\left[\mathbf{J}^{-\mathbf{2}} \cdot \mathbf{m m}^{-1}\right]}\end{array}$ \\
\hline $0 \mid 0$ & 6691 & 0.28 & 1.84 & 0.409 \\
$-40 \mid 0$ & 5878 & 0.32 & 1.89 & 2.231 \\
$-20 \mid 0$ & 8782 & 0.26 & 1.83 & 1.106 \\
$20 \mid 0$ & 8443 & 0.24 & 1.93 & 19.387 \\
$40 \mid 0$ & 7883 & 0.24 & 1.79 & 5.461 \\
$0 \mid-40$ & 6374 & 0.29 & 1.89 & 7.876 \\
$0 \mid-20$ & 6439 & 0.28 & 1.85 & 1.550 \\
$0 \mid 20$ & 5824 & 0.32 & 1.90 & 1.328 \\
$0 \mid 40$ & 4624 & 0.33 & 1.91 & 2.017 \\
\hline
\end{tabular}

A mean of 6751 drops per minute was gauged. The majority of the generated drops was included in the diameter classes $<0.50$ and $0.50-0.99 \mathrm{~mm}$, representing $92.9 \%$ (n 
= 6274) of all drops recorded. A comparison with the MPD shows that this is a pattern common for natural rainfall characteristics (Fig. 4a). Nevertheless, there are still notable deviations from the MPD, especially when viewing at the larger drop diameters. These drops were not listed in the mean drop spectrum (Fig. 3), as the raw data quantity was divided by the number of positions and datasets, therefore leading to mean drop counts smaller one drop per minute. The raw dataset of all drops counted at every position shows these few larger drops produced by the rainfall simulator (Table 3). It must be pointed out, that these drops with a diameter $>5 \mathrm{~mm}$ only accounted for $0.79 \%$ of all drops produced. Representing only a fraction of all drops counted, the deviation from MPD was seen as acceptable. Furthermore, larger drops were desired since it was assumed that the kinetic energy of the artificial rainfall was reduced compared to natural rainfall.

Table 3. Absolute and relative mean drop counts recorded at all LPM positions.

\begin{tabular}{ccc}
\hline Drop diameter [mm] & Drops counted in $\mathbf{1 5 9}$ minutes & Permillage [\%o] \\
\hline$<0.125$ & 0 & 0.00 \\
$0.125-0.249$ & 216,705 & 201.48 \\
$0.250-0.374$ & 274,295 & 255.02 \\
$0.375-0.499$ & 211,380 & 196.52 \\
$0.500-0.749$ & 237,068 & 220.41 \\
$0.750-0.999$ & 61,710 & 57.37 \\
$1.000-1.249$ & 29,224 & 27.17 \\
$1.250-1.499$ & 15,145 & 14.08 \\
$1.500-1.749$ & 9043 & 8.41 \\
$1.750-1.999$ & 5807 & 5.40 \\
$2.000-2.499$ & 6507 & 6.05 \\
$2.500-2.999$ & 3496 & 3.25 \\
$3.000-3.499$ & 1993 & 1.85 \\
$3.500-3.999$ & 1227 & 1.14 \\
$4.000-4.499$ & 715 & 0.66 \\
$4.500-4.999$ & 440 & 0.41 \\
$5.000-5.499$ & 291 & 0.27 \\
$5.500-5.999$ & 199 & 0.19 \\
$6.000-6.499$ & 115 & 0.11 \\
$6.500-6.999$ & 83 & 0.08 \\
$7.000-7.499$ & 50 & 0.05 \\
$7.500-7.999$ & 28 & 0.03 \\
$8.000-8.499$ & 68 & 0.06 \\
$>8.500$ & 0 & 0.00 \\
\hline Total & $1,075,589$ & 1000.00 \\
\hline
\end{tabular}

Decreased rainfall erosivity was caused by the construction-related low drop height of $2 \mathrm{~m}$ above ground, as described in section 2.2. A comparison between drop diameter and fall velocity derived from LPM data and natural rainfall (Fig. 4b) shows slightly higher fall velocities of small artificial drops but significantly lower fall velocities of large artificial 
drops. Especially these large drops produce the majority of rainfall kinetic energy. As they were falling slower than natural raindrops, a decreased rainfall kinetic energy ensued.

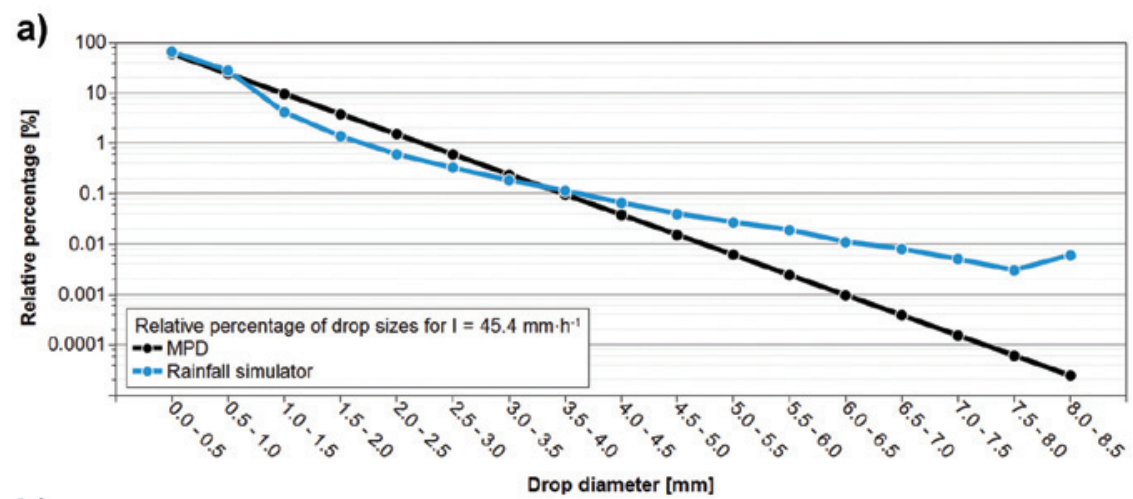

b)

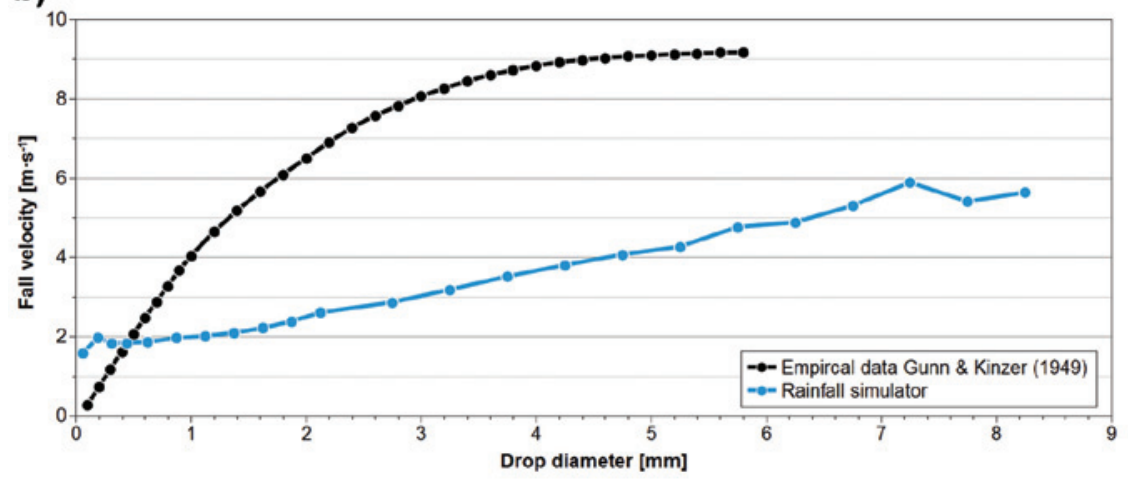

Figure 4. Comparison between empirical benchmarks and artificial rainfall: a) Artificial rainfall versus Marshall-Palmer Distribution (MPD)

(Marshall and Palmer, 1948); b) Artificial rainfall versus drop velocity data (Gunn and Kinzer, 1949).

Rainfall kinetic energy based on LPM data was only $4.6 \mathrm{~J} \cdot \mathrm{m}^{-2} \cdot \mathrm{mm}^{-1}$, while the kinetic energy of natural rainfall with the same intensity of $45.4 \mathrm{~mm} \cdot \mathrm{h}^{-1}$ was expected to be $26.1 \mathrm{~J} \cdot \mathrm{m}^{-2} \cdot \mathrm{mm}^{-1}$ according to van Dijk et al. (2002). Even though only $17.6 \%$ of the natural kinetic energy was achieved, it was the best possible compromise between rainfall homogeneity and erosivity, as an even lower operating pressure led to a complete collapse of the spray cone produced by the nozzle causing completely irregular and unpredictable spray patterns, making it impossible to adjust or replicate rainfall characteristics.

On the basis of LPM measurements, several datasets were interpolated on the plot surface and represented as contour maps to provide information about their spatial distribution. The interpolated datasets included mean drop count, median drop diameter, mean fall velocity and mean rainfall kinetic energy (Fig. 5). As the nine LPM positions 
were arranged in a crosswise pattern, a circular area with the presumably best quality data was on hand. Figure 5 shows both this circular area and the square plot surface boundary of $0.8 \cdot 0.8$ meters.

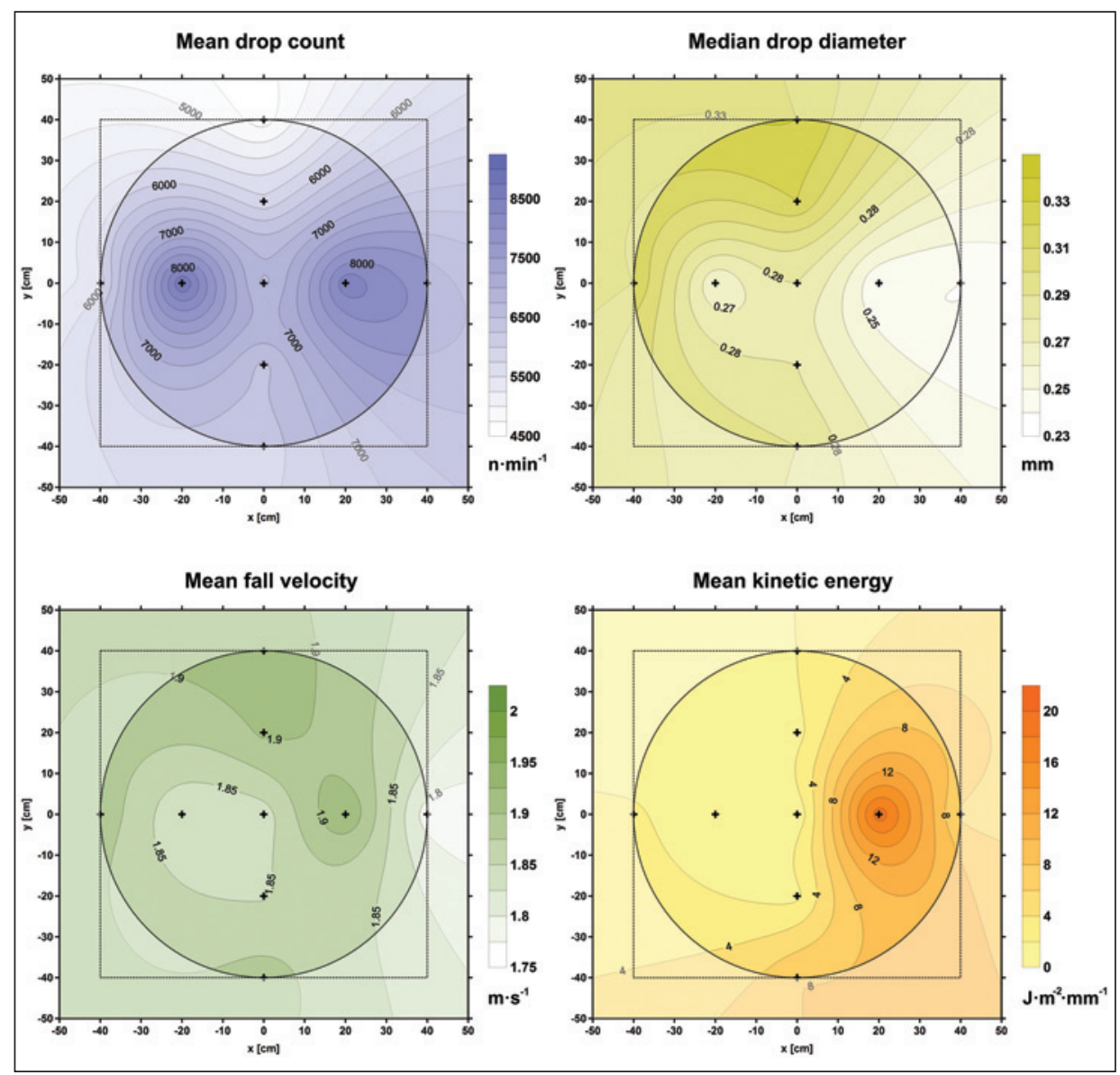

Figure 5. Interpolated results of LPM measurements: Mean drop count per minute, median drop diameter, mean fall velocity, mean rainfall kinetic energy.

The interpolated datasets represent the mean values for each position recorded. Regarding drop count, two distinct maxima at (-2010) and (2010) were reported. Simultaneously, the median drop diameter at these two positions was rather low, that is why these positions represent areas where a fine spray of artificial raindrops was on hand. Apart from that, the median drop diameter shows a homogeneous distribution, as the differences only reveal deviations within a range of $0.1 \mathrm{~mm}$. Mean fall velocities show a comparable pattern. Here, the range of recorded values lies within a span of only $0.25 \mathrm{~m} \cdot \mathrm{s}^{-1}$. 
Whereas the median drop diameter and mean fall velocity were virtually constant over the entire plot area, an unexpectedly inhomogeneous pattern in rainfall kinetic energy was calculated on the basis of the recorded drop spectrum. The highest values were recorded at position (20l0) with a $\mathrm{KE}$ of $19.39 \mathrm{~J} \cdot \mathrm{m}^{-2} \cdot \mathrm{mm}^{-1}$, a value $705 \%$ larger than that calculated for rest of the plot area, with a mean value of $2.75 \mathrm{~J} \cdot \mathrm{m}^{-2} \cdot \mathrm{mm}^{-1}$. This pattern can be explained by few large drops that were recorded at the corresponding position. In fact, the majority of all large drops $(>5 \mathrm{~mm})$ that were listed in Table 1 occurred at position (20l0). Table 4 provides the mean minute-based drop diameter counts and calculated KE-values for all positions recorded except position (2010) and the dataset obtained at position (20|0). Additionally, the relative quantities of drop count and KE are listed.

Table 4. Total and relative drop count and KE per minute based on drop diameter classes.

\begin{tabular}{|c|c|c|c|c|c|c|c|c|}
\hline \multirow{2}{*}{$\begin{array}{c}\text { Drop } \\
\text { diameter } \\
{[\mathrm{mm}]}\end{array}$} & \multicolumn{4}{|c|}{ LPM positions exclusive of $(20 \mid 0)$} & \multicolumn{4}{|c|}{ Position (20|0) } \\
\hline & n·min ${ }^{-1}$ & $\begin{array}{c}\text { Rel. n } \\
{[\% o]}\end{array}$ & $\begin{array}{c}\mathrm{KE} \\
{\left[\mathbf{J} \cdot \mathbf{m}^{-2} \cdot \mathbf{m m}^{-1}\right]}\end{array}$ & $\begin{array}{l}\text { Rel. } \\
\text { KE } \\
{[\% o]}\end{array}$ & $\mathbf{n} \cdot \mathbf{m i n}^{-1}$ & $\begin{array}{c}\text { Rel. n } \\
{[\% \text { ] }]}\end{array}$ & $\begin{array}{c}\mathrm{KE} \\
{\left[\mathbf{J} \cdot \mathbf{m}^{-2} \cdot \mathbf{m m}^{-1}\right]}\end{array}$ & $\begin{array}{l}\text { Rel. } \\
\text { KE } \\
{[\% \text { ] }}\end{array}$ \\
\hline$<0.125$ & 0.0 & 0.00 & 0.000 & 0.00 & 0.0 & 0.00 & 0.000 & 0.00 \\
\hline $0.125-0.249$ & 1293.0 & 195.73 & 0.000 & 0.37 & 2166.9 & 256.65 & 0.001 & 0.05 \\
\hline $0.250-0.374$ & 1639.6 & 245.11 & 0.007 & 6.60 & 2287.3 & 270.91 & 0.016 & 0.82 \\
\hline $0.375-0.499$ & 1289.4 & 194.15 & 0.016 & 17.05 & 1402.1 & 166.07 & 0.023 & 1.17 \\
\hline $0.500-0.749$ & 1475.8 & 227.91 & 0.045 & 47.44 & 1481.9 & 175.53 & 0.047 & 2.43 \\
\hline $0.750-0.999$ & 391.9 & 61.86 & 0.047 & 43.77 & 421.5 & 49.92 & 0.049 & 2.53 \\
\hline $1.000-1.249$ & 186.8 & 29.74 & 0.055 & 45.73 & 219.7 & 26.02 & 0.064 & 3.28 \\
\hline $1.250-1.499$ & 96.6 & 15.43 & 0.059 & 44.09 & 130.6 & 15.46 & 0.088 & 4.53 \\
\hline $1.500-1.749$ & 58.1 & 9.29 & 0.068 & 44.80 & 80.7 & 9.56 & 0.104 & 5.35 \\
\hline $1.750-1.999$ & 37.6 & 6.02 & 0.078 & 45.41 & 52.5 & 6.22 & 0.128 & 6.61 \\
\hline $2.000-2.499$ & 41.6 & 6.70 & 0.151 & 80.63 & 66.7 & 7.90 & 0.286 & 14.74 \\
\hline $2.500-2.999$ & 22.0 & 3.54 & 0.185 & 85.11 & 40.3 & 4.77 & 0.409 & 21.11 \\
\hline $3.000-3.499$ & 12.5 & 1.98 & 0.220 & 87.12 & 23.9 & 2.83 & 0.522 & 26.91 \\
\hline $3.500-3.999$ & 7.4 & 1.14 & 0.249 & 91.33 & 17.8 & 2.11 & 0.804 & 41.45 \\
\hline $4.000-4.499$ & 4.1 & 0.64 & 0.241 & 80.95 & 11.8 & 1.40 & 0.936 & 48.27 \\
\hline $4.500-4.999$ & 2.1 & 0.32 & 0.199 & 63.03 & 10.4 & 1.24 & 1.319 & 68.05 \\
\hline $5.000-5.499$ & 1.3 & 0.19 & 0.194 & 54.38 & 7.8 & 0.92 & 1.446 & 74.58 \\
\hline $5.500-5.999$ & 0.8 & 0.12 & 0.209 & 46.13 & 6.0 & 0.71 & 1.665 & 85.89 \\
\hline $6.000-6.499$ & 0.4 & 0.06 & 0.158 & 38.95 & 3.9 & 0.46 & 1.416 & 73.06 \\
\hline $6.500-6.999$ & 0.2 & 0.03 & 0.112 & 42.00 & 3.4 & 0.40 & 1.943 & 100.24 \\
\hline $7.000-7.499$ & 0.1 & 0.01 & 0.081 & 11.10 & 2.5 & 0.30 & 2.152 & 110.98 \\
\hline $7.500-7.999$ & 0.1 & 0.01 & 0.063 & 17.88 & 1.3 & 0.15 & 1.132 & 58.37 \\
\hline $8.000-8.499$ & 0.0 & 0.00 & 0.048 & 6.14 & 4.1 & 0.48 & 4.839 & 249.59 \\
\hline$>8.500$ & 0.0 & 0.00 & 0.000 & 0.00 & 0.0 & 0.00 & 0.000 & 0.00 \\
\hline Total & 6561.6 & 1000.00 & 2.487 & 1000.00 & 8442.9 & 1000.00 & 19.387 & 1000.00 \\
\hline
\end{tabular}


When viewing at these drop counts, two values are a matter of particular interest: considering the mean drop count per minute, position (2010) was one of the two maxima (Fig. 5). This is clearly seen when looking at the total mean drop count. All positions except (2010) showed a mean value of 6561.6 drops per minute, while drops counted at (2010) added up to a mean value of 8442.9 drops per minute. As described earlier, this was most likely due to a fine spray as the median drop diameter was much smaller. This can be confirmed when looking at drop diameter classes $0.125-0.249 \mathrm{~mm}$ and $0.250-0.374 \mathrm{~mm}$, where a higher drop count was recorded at (2010).

Yet, this does not explain the high KE values calculated at this position, as they can be ascribed almost solely to large drops. Raindrops with a diameter $>5 \mathrm{~mm}$ account for only $3 \%$ of all drops counted, but they produce $752 \%$ of all KE calculated. In view of drop counts, a mean value of only 29 raindrops per minute produces three-fourths of rainfall erosivity. This mismatch seems ostensible, but it eventually shows the massive influence that small amounts of larger drops have on rainfall erosivity. In contrast, the KE maxima of all other positions lie within the drop diameter range between 2.00 and $4.49 \mathrm{~mm}$. Here, $425 \%$ of the rainfall KE was calculated, produced by $14 \%$ of all drops recorded $\left(88 \mathrm{drops} \cdot \mathrm{min}^{-1}\right)$.

\section{Discussion}

The rainfall simulator presented in this study proved to be a reliable tool for investigating both runoff processes and soil erosion during several experiments (Zemke, 2016; Zemke and König, 2016). Constant monitoring of all simulator parameters during every simulation and the investigation of runoff processes showed a reliable and stable output (Zemke, 2016). A good example for assessing constant rainfall characteristics on the basis of results obtained in field experiments is the soil texture of eroded material. The majority of soil erosion during the simulations was most likely induced by splash effects, as the small dimensions of the plot frame restricted the formation of distinctive rills in which erosion processes by flowing water would have had occurred. This is why rainfall erosivity was most likely the driving force for particle detachment and transport.

A sedimentary analysis was conducted for each experiment, delivering mean soil textures for different surface categories. Figure 6 shows both particle size distribution and soil texture triangle for mixed samples taken in direct vicinity of the plots and for eroded particles.

Mean soil textures of mixed samples differed between surface categories (loamy sand for fortified roads and sandy loam for unfortified roads). That is plausible, as they represented two surfaces with a different degree of anthropogenic alteration. The median grain size was $212.9 \mu \mathrm{m}$ for unfortified roads and $332.5 \mu \mathrm{m}$ for fortified roads.

In contrast, it turned out that the eroded soil samples featured almost identical particle size distributions, as they both featured loam as mean soil texture with a striking similarity of their respective particle size curves (Fig. 6). The median grain sizes of eroded soil even lie within a range of only $2 \mu \mathrm{m}$, as it was $11.2 \mu \mathrm{m}$ for unfortified roads 
and $13.2 \mu \mathrm{m}$ for fortified roads. It is assumable, that this shift towards an almost identical grain size was caused by size-selective erosion of particles, limited by a most likely constant rainfall erosivity.

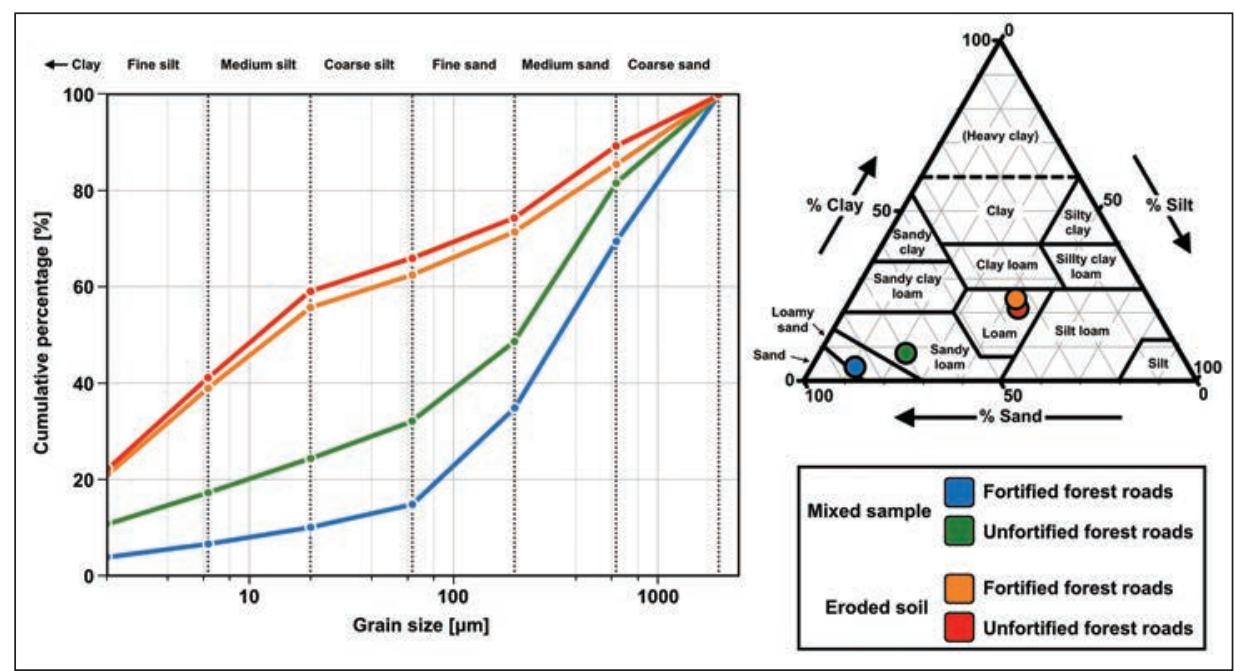

Figure 6. Particle size distributions and soil textures of samples taken during soil erosion simulations on fortified and unfortified forest roads. Mixed samples taken from road surfaces and samples with eroded material are indicated.

When viewing at the shortcomings of the simulator, a lack of rainfall erosivity has to be acknowledged, as only $17.6 \%$ of the potential kinetic energy for natural rainfall with the same intensity was obtained. This lack of rainfall kinetic energy is an inherent problem of the methodical setup that is not restricted to the rainfall simulator in this study. Out of thirteen simulators that were presented in Iserloh et al. (2013), twelve setups with similar specifications showed comparably low values, achieving results ranging from $2.9 \%$ to $50.2 \%$ (mean value: $27.4 \%$ ) of the potential kinetic energy on basis of their respective intensity. With regard to the presented simulator in this study, rainfall kinetic energy was also the only parameter obtained that showed a rather inhomogeneous spatial pattern with one position featuring increased values.

It cannot be ruled out that similar results would have occurred at other positions when measuring the drop spectra over a longer time period. Yet, considering that the time period in this study was three times longer than the standardized timespan presented in Iserloh et al. (2013) and that the measurements were conducted at nine instead of five positions as suggested in the same study, the result has to be acknowledged as given fact. Actually, the small number of drops that led to the inhomogeneous pattern shows that it would have been more plausible to expect an even more heterogeneous distribution of rainfall KE, since such a small percentage of deviating drops is not controllable or avoidable at all. Still, the rainfall simulator produces rainfall characteristics that are by far more stable than those of natural rainfall events. That is simply because of the 
incomparably higher number of external factors that influence natural rainfall like wind and turbulent air currents or the fluctuating rainfall intensity during a single rainfall event. Furthermore, a brief LPM examination of two natural rainfall events showed, that the recorded drop spectra also did not match the MPD or the empirical values of Gunn and Kinzer (1949) regarding drop diameter and fall velocity (Zemke, 2015).

Additionally, studies point out that empirical KE-Intensity relationships are valid only for their specific raw-data intensity range and climatic conditions, making it difficult to state a universal validity (Petan et al., 2010). The empirical equation presented in van Dijk et al. (2002), which was used as benchmark for the rainfall simulator, incorporates a wide margin of input parameters, making it a frequently used source and eventually a reliable choice for reviewing KE-Intensity relationships. Still, the authors depict deficits of the equation when comparing it to other studies (van Dijk et al., 2002). Even though it is generally correct to acknowledge low KE values produced by the simulator, a quantitative comparison with literature-based benchmarks always has a range of uncertainty.

In fact, rainfall $\mathrm{KE}$ is not the only parameter considered to describe rainfall erosivity. Many studies suggest that rainfall momentum might be an interchangeable or even better rainfall characteristic describing erosivity (Sanchez-Moreno et al., 2012; Brodie and Rosewell, 2007; Salles et al., 2001; Salles and Poesen, 2000). However, studies describing a momentum-intensity relationship are rather scarce. Iserloh et al. (2013) present an approach for calculating rainfall momentum out of LPM data, based on drop diameter and fall velocity classes. Using these equations, a momentum of 0.0077 $\mathrm{kg} \cdot \mathrm{m} \cdot \mathrm{s}^{-1}$ can be assumed for the generated artificial rainfall. In order to put this value in context, eight rainfall simulators with rainfall intensities in the range $\left( \pm 10 \mathrm{~mm} \cdot \mathrm{h}^{-1}\right)$ of the simulator presented in this study deliver a criterion (Iserloh et al., 2013): Their mean momentum achieved was $0.0146 \mathrm{~kg} \cdot \mathrm{m} \cdot \mathrm{s}^{-1}$ with a standard deviation of $0.008 \mathrm{~kg} \cdot \mathrm{m} \cdot \mathrm{s}^{-1}$. Hence, the existing simulator set-up delivers a result comparable to other systems.

Therefore, not only the evaluation of the generated rainfall characteristics is difficult, even the choice of variables describing rainfall erosivity is controversial. Still, considering all mentioned uncertainties, a conscientiously calibrated rainfall simulator, like the one presented in this study, is the best choice when analysing runoff and soil erosion processes at a small scale. For though simulators always exhibit methodological insecurities and shortcomings, at least they produce reliable and determinable boundary conditions.

\section{Conclusions}

A small-scale rainfall simulator was successfully built and calibrated, meeting all of the major requirements formulated at the beginning of the conceptual planning. It features a lightweight rack and portable equipment allowing flexible operations in rough terrain. Apart from that, the rainfall characteristics meet most of the desired standards concerning homogeneity and intensity, while the inevitable shortcomings of rainfall erosivity are at least predictable and show no deviations that differ significantly from other simulator 
setups. Nevertheless, the high-precision calibration using different LPM-positions on the plot surface combined with an interpolation of the derived rainfall characteristics revealed heterogeneity that was caused by only a fraction of drops. The results show that rainfall simulators -especially when experiments in the field are conductedshow an inherent uncertainty of rainfall characteristics when these are surveyed with a high spatial and/or temporal resolution. This study shall provide a positive error culture when discussing rainfall simulator specifications in terms of acknowledging inevitable errors that might occur. Yet, these errors have to be minimized as far as possible.

\section{References}

Arnaéz, J., Lasanta, T., Ruiz-Flaño, P., Ortigosa, L. 2007. Factors affecting runoff and erosion under simulated rainfall in Mediterranean vineyards. Soil and Tillage Research 93 (2), 324334. http://doi.org/10.1016/j.still.2006.05.013.

Arnáez, J., Larrea, V., Ortigosa, L. 2004. Surface runoff and soil erosion on unpaved forest roads from rainfall simulation tests in northeastern Spain. Catena 57 (1), 1-14. http://doi. org/10.1016/j.catena.2003.09.002.

Arnáez, J., Larrea, V. 1995. Erosion Processes and Rates on Road-Sides of Hill-Roads (Iberian System, La Rioja, Spain). Physics and Chemistry of the Earth 20 (3-4), 395-401. http://doi. org/10.1016/0079-1946(95)00053-4.

Assouline, S. 2009. Drop size distributions and kinetic energy rates in variable intensity rainfall. Water Resources Research 45 (11), W11501. http://doi.org/10.1029/2009WR007927.

Blanquies, J., Scharff, M., Hallock, B. 2003. The Design and Construction of a Rainfall Simulator. Presented at the International Erosion Control Association (IECA), $34^{\text {th }}$ Annual Conference and Exposition, Las Vegas, Nevada, February 24-28, 2003. Caltrans Storm Water Program. Office of Water Programs, California State University, Sacramento. PP044.

Brodie, I., Rosewell, C. 2007. Theoretical relationships between rainfall intensity and kinetic energy variants associated with stormwater particle washoff. Journal of Hydrology 340 (12), 40-47. http://doi.org/10.1016/j.jhydrol.2007.03.019.

Butzen, V., Seeger, M., Wirtz, S., Huemann, M., Müller, C., Casper, M., Ries, J.B. 2014. Quantification of Hortonian overland flow generation and soil erosion in a Central European low mountain range using rainfall experiments. Catena 113, 202-212. http://doi. org/10.1016/j.catena.2013.07.008.

Cerdà, A., Ibáñez, S., Calvo, A. 1997. Design and operation of a small portable rainfall simulator for rugged terrain. Soil Technology 11 (2), 163-170. http://doi.org/10.1016/S09333630(96)00135-3.

Chaubey, I., Haan, C.T., Grunwald, S., Salisbury, J.M. 1999. Uncertainty in the model parameters due to spatial variability of rainfall. Journal of Hydrology 220 (1-2), 48-61. http://doi. org/10.1016/S0022-1694(99)00063-3.

Christiansen, J.E. 1942. Irrigation by sprinkling. California Agricultural Experimental Station Bulletin 670, University of California, Berkeley.

De Vente, J., Poesen, J., Verstraeten, G., Govers, G., Vanmaercke, M., Van Rompaey, A., Arabkhedri, M., Boix-Fayos, C. 2013. Predicting soil erosion and sediment yield at regional scales: where do we stand? Earth-Science Reviews 127, 16-29. http://doi.org/10.1016/j. earscirev.2013.08.014.

Dunkerley, D. 2008. Rain event properties in nature and in rainfall simulation experiments: a comparative review with recommendations for increasingly systematic study and reporting. Hydrological Processes 22 (22), 4415-4435. http://doi.org/10.1002/hyp.7045. 
Edwards, W.M., Owens, L.B. 1991. Large storm effects on total soil erosion. Journal of Soil and Water Conservation 46 (1), 75-78.

Foltz, R.B., Copeland, N.S., Elliot, W.J. 2009. Reopening abandoned forest roads in northern Idaho, USA: Quantification of runoff, sediment concentration, infiltration, and interrill erosion parameters. Journal of Environmental Management 90, 2542-2550. http://doi. org/10.1016/j.jenvman.2009.01.014.

Fornis, R.L., Vermeulen, H.R., Nieuwenhuis, J.D. 2005. Kinetic energy-rainfall intensity relationship for Central Cebu, Philippines for soil erosion studies. Journal of Hydrology 300 (1-4), 20-32. http://doi.org/10.1016/j.jhydrol.2004.04.027.

Fransen, P.J.B., Phillips, C.J., Fahey, B.D. 2001. Forest Road Erosion in New Zealand: Overview. Earth Surface Processes and Landforms 26 (2), 165-174. http://doi.org/10.1002/10969837(200102)26:2<165::AID-ESP170>3.0.CO;2-\#.

Gunn, R., Kinzer, G.D. 1949. The terminal velocity of fall for water droplets in stagnant air. Journal of Meteorology 6, 243-248. http://doi.org/10.1175/1520-0469(1949)006<0243:TT $\mathrm{VOFF}>2.0 . \mathrm{CO} ; 2$.

Iserloh, T., Ries, J.B., Arnáez, J., Boix Fayos, C., Butzen, V., Cerdà, A., Echeverría, M.T., Fernández-Gálvez, J., Fister, W., Geißler, C., Gómez, J.A., Gómez-Macpherson, H., Kuhn, N.J., Lázaro, R., León, F.J., Martínez-Mena, M., Martínez-Murillo, J.F., Marzen, M., Mingorance, M.D., Ortigosa, L., Peters, P., Regüés, D., Ruiz-Sinoga, J.D., Scholten, T., Seeger, M., Solé-Benet, A., Wengel, R., Wirtz, S. 2013. European small portable rainfall simulators: a comparison of rainfall characteristics. Catena 110, 100-112. http:// doi.org/10.1016/j.catena.2013.05.013.

Iserloh, T., Fister, W., Seeger, M., Willger, H., Ries, J.B. 2012. A small portable rainfall simulator for reproducible experiments on soil erosion. Soil and Tillage Research 124, 131-137. http:// doi.org/10.1016/j.still.2012.05.016.

MacDonald, L.H., Sampson, R.W., Anderson, D.M. 2001. Runoff and Road Erosion at the Plot and Road Segment Scales, St. John, US Virgin Islands. Earth Surface Processes and Landforms 26 (2), 251-272. http://doi.org/10.1002/1096-9837(200103)26:3<251::AIDESP173>3.0.CO;2-X.

Maetens, W., Vanmaercke, M., Poesen, J., Jankauskas, B., Jankauskiene, G., Ionita, I. 2012. Effects of land use on annual runoff and soil loss in Europe and the Mediterranean. A meta-analysis of plot data. Progress in Physical Geography 36 (5), 599-653. http://doi. org/10.1177/0309133312451303.

Marshall, J.S., Palmer, W.McK. 1948. The distribution of raindrops with size. Journal of Meteorology 5, 165-166. http://doi.org/10.1175/1520-0469(1948)005<0165:TDORWS $>2.0$ .CO;2.

Morgan, R.P.C. 2009. Soil erosion and Conservation. $3^{\text {rd }}$ ed. Wiley-Blackwell, Oxford, 320 pp.

Morin, E., Goodrich, D.C., Maddox, R.A., Gao, X., Gupta, H.V., Sorooshian, S. 2006. Spatial patterns in thunderstorm rainfall events and their coupling with watershed hydrological response. Advances in Water Resources 29 (6), 843-860. http://doi.org/10.1016/j. advwatres.2005.07.014.

Petan, S., Rusjan, S., Vidmar, A., Mikoš, M. 2010. The rainfall kinetic energy-intensity relationship for rainfall erosivity estimation in the mediterranean part of Slovenia. Journal of Hydrology 391 (3-4), 314-321. http://doi.org/10.1016/j.jhydrol.2010.07.031.

Ries, J.B., Seeger, M., Iserloh, T., Wistorf, S., Fister, W. 2009. Calibration of simulated rainfall characteristics for the study of soil erosion on agricultural land. Soil and Tillage Research 106 (1), 109-116. http://doi.org/10.1016/j.still.2009.07.005.

Rodrigo Comino, J., Iserloh, T., Lassu, T., Cerdà, A., Keestra, S.D., Prosdocimi, M., Brings, C., Marzen, M., Ramos, M.C., Senciales, J.M., Ruiz Sinoga, J.D., Seeger, M., Ries, J.B. 2016. 
Quantitative comparison of initial soil erosion processes and runoff generation in Spanish and German vineyards. Science of The Total Environment 565, 1165-1174. http://doi. org/10.1016/j.scitotenv.2016.05.163.

Salles, C., Poesen, J., Govers, G. 2001. A comparison of rain erosivity parameters for predicting soil detachment on interrills. In Sustaining the Global Farm. Selected papers from the 10th International Soil Conservation Organization Meeting held May 24-29, 1999 at Purdue University and the USDA-ARS National Soil Erosion Research Laboratory. D.E. Stott; R.H. Mohtar; G.C. Steinhardt (ed.), National Soil Erosion Laboratory, West Lafayette, Indiana, pp. 834-837.

Salles, C., Poesen, J. 2000. Rain properties controlling soil splash detachment. Hydrological Processes 14(2),271-282.http://doi.org/10.1002/(SICI)1099-1085(20000215)14:2<271::AIDHYP925>3.0.CO;2-J.

Sanchez-Moreno, J.F., Mannaerts, C.M., Jetten, V., Löffler-Mang, M. 2012. Rainfall kinetic energy-intensity and rainfall momentum-intensity relationships for Cape Verde. Journal of Hydrology 454-455, 131-140. http://doi.org/10.1016/j.jhydrol.2012.06.007.

Usón, A., Ramos, M.C. 2001. An improved rainfall erosivity index obtained from experimental interrill soil losses in soils with a Mediterranean climate. Catena 43 (4), 293-305. http://doi. org/10.1016/S0341-8162(00)00150-8.

Van Dijk, A.I.J.M., Bruijnzeel, L.A., Roswell, C.J. 2002. Rainfall intensity - kinetic energy relationships: a critical literature appraisal. Journal of Hydrology 261 (1-4), 1-23. http://doi. org/10.1016/S0022-1694(02)00020-3.

Zemke, J.J. 2016. Simulation of runoff and erosion on forest roads using a small scale rainfall simulator. Hydrology 2016, 3 (3), 25. Special Issue "Rainfall Simulators as a tool in Soil Science, Geomorphology and Hydrology research and teaching". http://doi.org/10.3390/ hydrology3030025.

Zemke, J.J., König, D. 2016. Abflussbildung und Bodenerosion auf Forstwegen. Geographische Rundschau 1/2016, 46-53.

Zemke, J.J. 2015. Simulation und Modellierung von Oberflächenabfluss und Bodenabtrag auf Wirtschaftswegen in Bewaldeten Einzugsgebieten. Ph.D. Thesis, University of KoblenzLandau, Koblenz, Germany, 11 November 2014. 